\title{
Integumental ulcerative disease in a loggerhead turtle Caretta caretta at the Bermuda Aquarium: microbiology and histopathology
}

\author{
Michael Wiles ${ }^{1}$, Thomas G. Rand ${ }^{2}$ \\ ${ }^{1}$ Biology Department, Saint Mary's University, Halifax, Nova Scotia B3H 3C3, Canada \\ ${ }^{2}$ Bermuda Aquarium, Museum and Zoo, Flatts, Smiths 3, Bermuda
}

\begin{abstract}
A large loggerhead turtle at the Bermuda Aquarium was afflicted with severe integumental necrosis which failed to respond to standard treatments. Gross lesions were subcutaneous and creamy white areas and haemorrhagic ulcerations of the skin with tissue destruction, erythrema and exudation. A mixed infection of Acinetobacter calcoaceticus var Lwoffi, Acinetobacter-like, Pasteurella-like, Proteus-like, and Salmonella-like strains, Vibrio alginolyticus, V. parahaemolyticus, a non-identified myxobacterial strain and an irregularly branched, septate fungus occurred in the lesions. Histopathological features were localized epidermal proliferation and destruction, formation of granulation tissue, increased vascularization of the dermis underlying affected epidermis, and changes in melanophore, lymphocyte and eosinophilic granulocyte abundance. These results confirm findings of previous studies that mixed infections of known pathogens plus other potentially harmful aquatic heterotrophs are associated with sea turtle skin diseases. Possibly, poor environmental quality was a major factor that exacerbated this condition by debilitation of the afflicted turtle.
\end{abstract}

\section{INTRODUCTION}

During the last $5 \mathrm{yr}$, captive marine turtles in the Bermuda Aquarium, Museum and Zoo have been seen to be regularly afflicted with ulcerative shell and skin diseases. Various treatments have been tried, including topical applications of either saturated potassium permanganate solution or hydrogen peroxide, oral administration of oxytetracycline (12 $\mathrm{mg} \mathrm{kg}^{-1}$ ) to the affected turtles, and intramuscular injections $(10 \mathrm{mg}$ $\mathrm{kg}^{-1}$ ). These therapies have resulted in elimination or control of these conditions in most diseased specimens. However, chronic severe integumental necrosis in a large loggerhead turtle Caretta caretta L. failed to respond to any of the treatments which were tried. The disease started at an unknown time prior to May 1981 when one of us (T.G.R.) commenced employment at the Aquarium. This paper describes our microbiological and histopathological study of the largest lesion in this example of integumental disease in a loggerhead turtle.

\section{MATERIALS AND METHODS}

The afflicted loggerhead turtle weighed $75.9 \mathrm{~kg}$. Its plastron measured $74.4 \mathrm{~cm}$ long by $61.6 \mathrm{~cm}$ wide. The outer surface of the most extensive lesion was sterilized by several applications of $70 \%$ ethanol. Pieces of diseased tissue from that site were then biopsied, placed into sterile Petri dishes and taken to the laboratory. Wet mounts of smears made from some of the biopsied tissues were examined by phase contrast illumination using a Leitz Dialux 22 microscope or allowed to air dry and then stained with Gram stains for microorganisms. Live and heat-fixed bacteria, and fungi in sections, were measured by use of an acular micrometer. A sterile inoculating needle was scraped over the surface of the biopsy specimen and streaked on Petri dishes containing Bermuda seawater agar (BSA), MacConkey's agar (MA), Ordal's minimal medium (OMM), triple sugar iron agar (TSIA), and tryptic soy agar (TSA). OMM consists of $0.5 \mathrm{~g}$ tryptone, $0.5 \mathrm{~g}$ yeast extract, $0.2 \mathrm{~g}$ beef extract, $0.2 \mathrm{~g}$ sodium acetate and $9 \mathrm{~g}$ 
agar; BSA is $9 \mathrm{~g}$ agar, all amounts being per litre of seawater. Petri dishes were incubated at room temperature $\left(25^{\circ} \mathrm{C}\right)$ for $2 \mathrm{~d}$. Hanging drop (HD) preparations were made from samples of colonies and examined with phase contrast illumination. Biochemical profiles of the bacterial isolates were determined by means of API $20 \mathrm{E}$ test strips (Analytical Products, New York) and incubated at room temperature. Generic determinations were made by using both the API identification manual and the eighth edition of Bergey's Manual of Determinative Bacteriology (Buchanan \& Gibbons 1974).

The remaining portions of the biopsy specimens were fixed in $10 \%$ formalin in seawater ( $\mathrm{pH} 7.4$ ) almost immediately after their removal from the turtle. They were then rinsed in tap water, dehydrated in an ethanol series, cleared in xylene, embedded in paraffin wax and sectioned at 4 to $5 \mu \mathrm{m}$ thick. Tissue sections were stained by haematoxylin and eosin (H \& E), Pollack's rapid trichrome staining method, Brown and Brenn modified Gram stain, the periodic acid-Schiff reagent (PAS), Hutchinson's iron reaction for haemosiderin, and Lillie's ferrocyanide method (Humason 1972).

\section{RESULTS}

Gross signs of disease consisted of many lesions in the skin of the neck, tail, and axillary and inguinal regions (Fig. 1) and also in the shell plates near the rear margin of the left side of the head (Fig. 2). Lesions ranged in size between small $(<0.5 \mathrm{~cm})$, shallow, ovoid to round, creamy white to greyish areas and larger $(6 \mathrm{~cm})$, haemorrhagic ulcers, and ventrally an extensive area (>15 cm across) of severe dermal necrosis between the plastron and tail. Tissues around the larger lesions were inflamed and raised above the surface of the surrounding healthy skin. The last mentioned lesion was mostly granular to the touch. Bleeding began whenever the 'crust' was removed and petechiation and/or bleeding occurred in those areas of the lesion not covered by it. In addition to the skin and shell lesions, there was a marked prolapse of the cloaca (Fig. 1). Moreover, this individual was often lethargic and inappetent.

Observations of smears and HD slides of diseased tissues showed the presence of several different morphological types of bacteria, as follows: very long. kinked non-motile rods over $20 \mu \mathrm{m}$; straight, thin motile rods about $10 \mu \mathrm{m}$ long; slender non-motile rods 3 to $6 \mu \mathrm{m}$ long; curved motile rods 2 to $3 \mu \mathrm{m}$ long; short, straight motile rods 2 to $3 \mu \mathrm{m}$ long; motile coccobacilli in pairs; and non-motile cocci about $1 \mu \mathrm{m}$ in diameter. Heavy growth of a mixture of these types was obtained on TSIA. Subcultures on BSA, TSA and TSIA yielded pure colonies which were sampled and inocu- lated onto the API test strips. Results of the biochemical tests are given in Table 1. Eight types of bacteria were isolated, as follows: Acinetobacter calcoaceticus var. Lwoffi; an Acinetobacter-like strain; a Pasteurella-like form; a Proteus-like strain; a Salmonella-like form; Vibrio alginolyticus; $V$. parahaemolyticus; and an unidentified myxobacterial type. The last-named formed irridescent yellow-orange colonies on BSA, MA and TSA media, measured 3 to $6 \mu \mathrm{m}$ long by $0.5 \mu \mathrm{m}$ wide, formed chains and was oxidase and catalase positive.

Table 1. Biochemical characteristics of bacterial isolates from an integumental lesion of a loggerhead turtle at the Bermuda Aquarium. Isolate numbers: 1, Acinetobacter calcoaceticus var. Lwoffi; 2. Acinetobacter-like strain; 3, Pasteurella-like strain; 4, Proteus-like strain; 5, Salmonella-like strain; 6, Vibrio alginolyticus; 7 , Vibrio parahaemolyticus; 8 , unidentified myxobacterial strain

\begin{tabular}{|c|c|c|c|c|c|c|c|c|}
\hline \multirow[t]{2}{*}{ Test } & \multicolumn{8}{|c|}{ Isolate number } \\
\hline & 1 & 2 & 3 & 4 & 5 & 6 & 7 & 8 \\
\hline ONPG ( $\beta$-galactosidase) & - & - & - & - & - & - & - & - \\
\hline Arginine dihydrolase & - & - & - & - & - & + & - & - \\
\hline Lysine decarboxylase & - & - & - & - & + & + & + & - \\
\hline Ornithine decarboxylase & - & + & - & + & + & - & - & - \\
\hline Citrate utilization & - & + & - & + & + & - & - & - \\
\hline $\mathrm{H}_{2} \mathrm{~S}$ production & - & - & - & - & - & - & - & - \\
\hline Urease & - & - & - & - & - & - & + & - \\
\hline Tryptophane deaminase & - & - & - & + & - & - & - & - \\
\hline Indole & - & - & + & - & + & + & + & - \\
\hline Voges-Proskauer & - & - & - & - & - & - & - & - \\
\hline Gelatinase & + & + & - & + & + & + & + & - \\
\hline \multicolumn{9}{|l|}{ Acid from: } \\
\hline Glucose & - & - & - & - & + & + & + & - \\
\hline Mannitol & - & - & - & - & + & + & + & - \\
\hline Inositol & - & - & - & - & - & - & - & - \\
\hline Sorbitol & - & - & - & - & - & - & - & - \\
\hline Rhamnose & - & - & - & - & - & - & - & - \\
\hline Sucrose & - & + & - & - & + & + & + & - \\
\hline Melibiose & - & - & - & - & - & - & - & - \\
\hline Amygdalin & - & - & - & - & + & + & + & - \\
\hline Arabinose & - & + & - & - & - & - & - & - \\
\hline $\mathrm{NO}_{2}-\mathrm{NO}_{3}$ & - & - & - & - & + & + & + & - \\
\hline$N_{2}$ production & - & - & - & - & - & - & - & - \\
\hline Motility & - & + & - & + & - & - & - & - \\
\hline \multicolumn{9}{|l|}{ Growth on: } \\
\hline ISA & - & + & + & + & + & + & + & $(+)$ \\
\hline MacConkey's & - & + & + & + & + & + & + & - \\
\hline $\mathrm{BSA}$ & - & + & + & + & + & + & + & $(+)$ \\
\hline OMM & - & + & + & + & + & + & + & $(+)$ \\
\hline OF-oxidation & - & + & + & - & + & + & + & - \\
\hline OF-fermentation & - & + & + & - & + & + & + & - \\
\hline Cytochrome oxidase & - & + & + & + & + & + & + & - . \\
\hline Catalase & - & - & - & + & + & + & + & + \\
\hline Gram stain & - & - & - & - & - & - & - & - \\
\hline $\begin{array}{l}+ \text { : positive }- \text {. negative; } \\
\quad \text { up to } 36 \mathrm{~h} \text { only. " Slov }\end{array}$ & & & & & & & & or \\
\hline
\end{tabular}



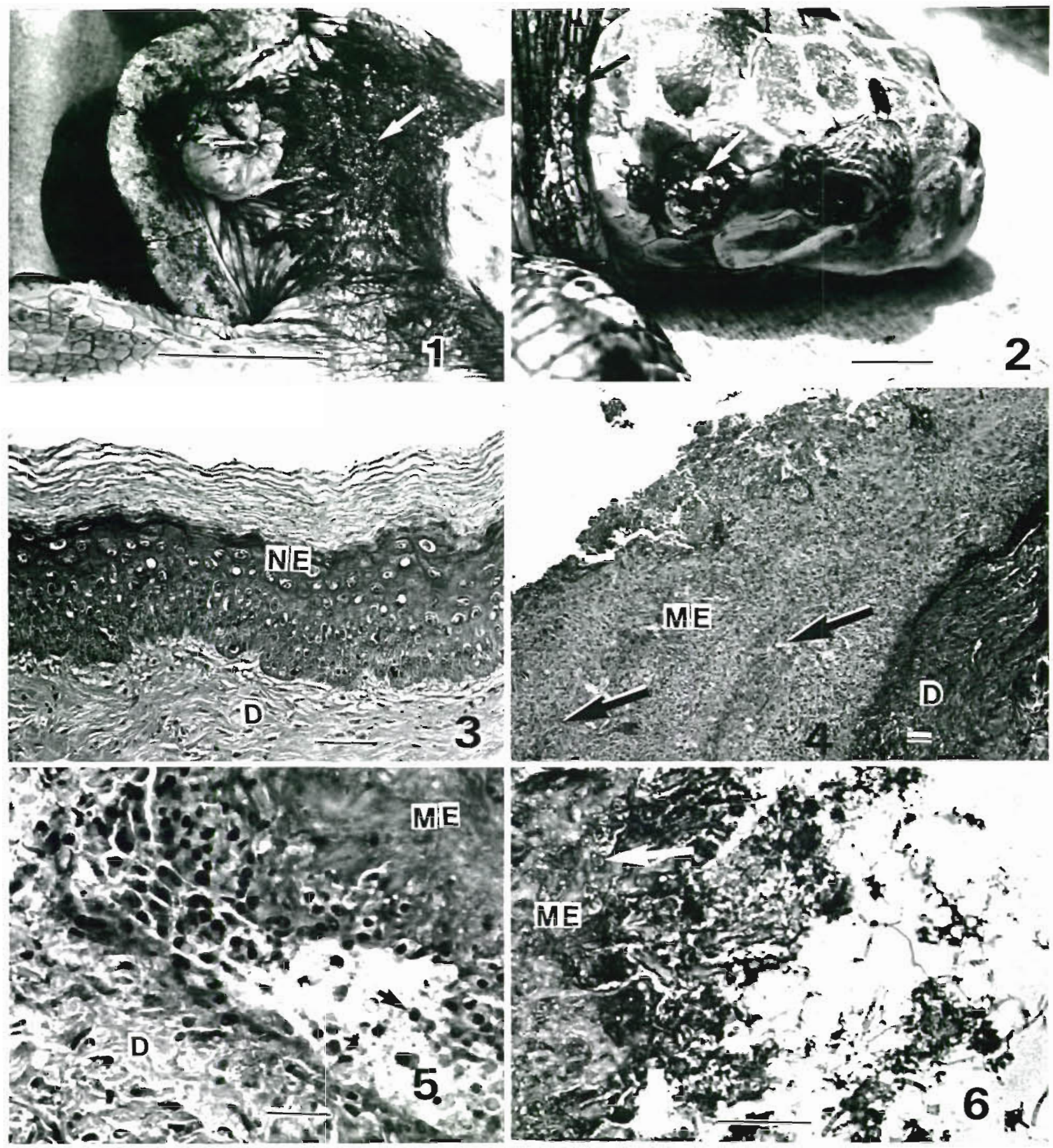

Fig. 1 to 6. Caretta caretta. Fig. 1. Ventral view of anal region, with a massive skin lesion (arrow) and prolapsed cloaca. (Scale bar $=15 \mathrm{~cm}$.) Fig. 2. Lateral view of head region showing both skin and carapace plate lesions (arrows). (Scale bar $=5 \mathrm{~cm}$. ) Fig. 3.

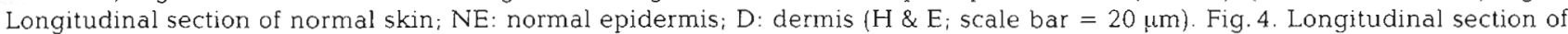
skin tissue from a lesion of $C$. caretta with ulcerative integumental disease showing the highly modified epidermis (ME) with its characteristic longitudinal basophilic bands (arrows); D: dermis; (H \& E; scale bar $=10 \mu \mathrm{m}$ ). Fig. 5 . Longitudinal section of skin tissue in a lesion area showing vascularization between the modified epidermis (ME) and dermis (D); arrow: lymphocyte; (H \& E; scale bar $=20 \mu \mathrm{m}$ ). Fig. 6 . Longitudinal section of a lesion area showing myriads of microorganisms on the surface and granular

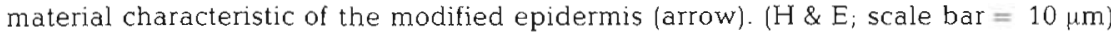

Compared with normal loggerhead turtle integument (Fig. 3), the diseased skin showed localized epidermal proliferation and destruction (Fig. 4). The outermost layer ('crust') of the excised tissue was a highly modified epidermis (ME) consisting of an acellular, granular material (AGM) containing pycnotic nuclei. The surface 
of the ME was bounded by a narrow basophilic zone which contained deep pits and was sloughing. The ME lacked the epidermal layers of normal loggerhead integument. However, it was marked by several almost regularly occurring, narrow longitudinal, basophilic bands. The ME was demarcated from the underlying dermis by a zone of loose irregular connective tissue with enlarged lymph or blood vessels containing lymphocytes, eosinophilic granulocytes (Fig.5) and melanophores. Superficially, the ME was covered in many places by myriads of Gram-negative bacteria of several different morphological types (Fig.6). Bacteria were present at all depths in the pits, but did not occur within the matrix of the AGM itself. In sections stained with PAS, irregularly branching, septate fungal hyphae, 1 to $3 \mu \mathrm{m}$ wide and up to $35 \mu \mathrm{m}$ long, were seen on the surface of, and within, the AGM and within the dermis (Fig. 7). The ME was brittle and friable in paraffin sections when dehydrated and cleared and often cracked when transferred to slides. The dermis contiguous to the ME was composed of apparently nondegenerative granulation tissue (Fig. 8) containing fibroblasts, lymphocytes and melanophores. However, apart from the presence of fungal hyphae, deeper dermal layers appeared normal. Both ciseased and normal tissues lacked haemosiderin and melanin pigments.

\section{DISCUSSION}

Skin diseases are common in captive marine turtles (Glazebrook 1981). They are caused by abrasions, bacteria, bite wounds, parasites, fungi, viruses, neoplasia and trauma (Frye 1973, Rebell et al. 1975, Billups \& Harshbarger 1976, Marcus 1980, Cooper \& Jackson 1981, Hoff et al. 1984, Migaki et al. 1984). However, aquatic heterotrophic bacteria are regarded as the most common cause of skin lesions in marine turtles (Anonymous 1979). The bacteria reported from diseased skin include Aeromonas hydrophila, Citrobacter (= Escherichia) freundii, Beneckea chitinovora, Bacillus, Citrobacter, Enterobacter, Flavobacterium, Micrococcus, Pasteurella, Proteus, Pseudomonas fluorescens, Salmonella, Serratia, Vibrio alginolyticus and Peptostreptococcus spp. (Reichenbach-Klinke \& Elkan 1965, Jackson \& Fulton 1970, Frye 1973, Wallach 1976, Glazebrook 1981, Hoff et al. 1984).

Although bacterial skin diseases of turtles have often been attributed to infection with a single aetiological agent (Hoff et al. 1984) several studies (Jackson \& Fulton 1970, Marcus 1980, Glazebrook 1981) have shown that several bacterial types are associated with some of these diseases. Glazebrook (1981) reported a mixed infection consisting of various Gram-negative bacteria as the cause of ulcerative dermatitis in captive green turtles Chelonia mydas (L.) in Australia. Jackson et al. (1972) recovered a mixture of Gram-negative bacilli from abscesses in the integument of the eastern box turtle Terrapene carolina. Jackson \& Fulton (1970) similarly reported a mixed infection of 5 types of bacteria from cutaneous lesions in the painted turtle Chrysemys picta. Moreover, these 2 workers suggested that the skin lesions were caused by the synergistic activities of 2 of these bacterial types, namely Serratia and Citrobacter spp.

Fungal skin diseases in captive marine turtles are thought to be of major importance (Frye 1973). However, specific information on them is rare in the literature according to Austwick \& Keymer (1981), who list only 2 reports from them, namely Fusarium solani from loggerhead turtle and unidentified septate hyphae from green turtle. All fungi so far identified from turtle

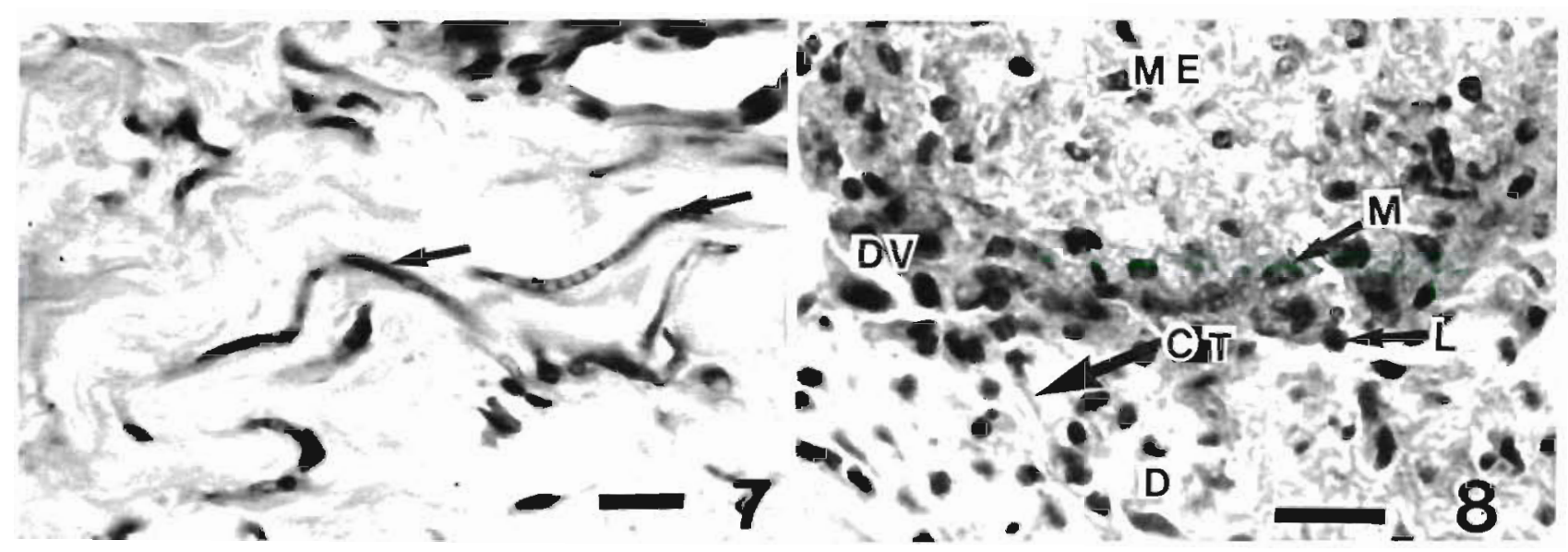

Fig. 7 \& 8. Fig. 7. Longitudinal section of dermis showing irregularly branching seplate hyphae (arrows) (PAS; scale bar $=10$ !um) Fig. 8. Longitudinal section of a lesion region showing an area of granulation tissue; $C T$ : connective tissue; $D$ : dermis; DV dermal vessel; L: lymphocytes; $\mathrm{M}$ : melanophores; ME: modified epidermis. (H \& E: scale bar $=10 \mu \mathrm{m}$ ) 
skin lesions are common saphrophytes so that their role in disease is unclear (Austwick \& Keymer 1981).

The gross lesions described by Glazebrook (1981) resembled those seen in the present study, except that the large ventral lesion in our loggerhead turtle was over 3 times the size of any seen on the green turtle. Vibrio alginolyticus and Proteus spp. were isolated by Glazebrook (1981) in common with our findings, whereas Aeromonas hydrophila was not recovered in either study. The occurrence of $V$. alginolyticus in turtles from both Bermuda and Australia is interesting because it is regarded as a pathogen of many marine animals (Buchanan \& Gibbons 1984). Gross lesions in aquatic turtles caused by fungi (Migaki et al. 1984) also resemble those seen in the present study. However, we also isolated 2 other known bacterial pathogens of stressed marine vertebrates, Acinetobacter calcoaceticus and Vibrio parahaemolyticus, and several other opportunistic species that are regarded as potentially pathogenic. Thus, we suggest that the loggerhead turtle was affected with a fungal and mixed bacterial infection of the skin. That $A$. hydrophila was absent in this individual is notable because it occurs in Bermuda seawater (Wiles \& Rand unpubl.) and we cultured it from both the turtle's tank water and diseased eye exudates of green and hawksbill (Eretmochelys imbricata (L.) turtles in the Bermuda Aquarium in 1983 and 1984. Thus the loggerhead turtle appears to be resistant to $A$. hydrophila, although it is a well-known virulent pathogen of many species of aquatic organisms, including furtles, around the world. Poor environmental quality is a major contributory factor that exacerbates stress-mediated diseases in captive aquatic animals (Wedemeyer \& Wood 1974). As it is most difficult to control water quality in large holding facilities without filters capable of removing microorganisms (an expensive process), mixed microbial infections are, not surprisingly, being commonly reported today in public aquariums worldwide.

Superficially, lesions described here resemble those reported by Kaplan (1957), Jackson \& Fulton (1970), Witham (1972), Glazebrook (1981), Hoff (1984), Hoff \& Hoff (1984), Jacobson (1984), Migaki et al. (1984) and Shotts (1984), on either terrapins or turtles with bacterial or fungal skin diseases in that they were cutaneous, spreading, and ulcerative. However, none of these earlier studies provided any histopathological details of the lesions. The present work shows that striking nonspecific histological changes take place throughout affected integumental tissues. These changes include localized epidermal proliferation and destruction, formation of granulation tissue, increased vascularization of the dermis underlying affected epidermis, changes in melanophore abundance and infiltration by lymphocytes and eosinophilic granulocytes. Some of these changes have been described in certain other turtle skin diseases. For example, Rebell et al. (1975) reported proliferative epidermal changes together with leukocytic infiltration and increased vascularity of dermis underlying lesions in green turtles with a herpesvirustype skin infection. Striking features of the loggerhead turtle skin disease are the severely modified epidermis, with its acellular granular substance consisting of accumulated cellular debris and the regularly arranged longitudinal basophilic bands. The AGM may be the result of the bacteria and fungi associated with the $\mathrm{ME}$ releasing substances that modify the keratinous epidermal layers by extracellular digestion. Alternatively, the changes to the epidermis may be a host response to this chronic ulcerative skin disease whereby the tissues are transformed into an almost homogeneous, necrotic 'crust'.

\section{LITERATURE CITED}

Anonymous (1979). The Merck veterinary manual. 5th edn Merck, Rathway, New Jersey

Austwick, P. K. C., Keymer, I. F. (1981). Fungi and Actinomycetes. In: Cooper, J. E., Jackson, O. F. (ed.) Diseases of the Reptilia, Vol. I. Academic Press, London, p. 192-230

Billups, L. H., Harshbarger, J. C. (1976). Reptiles. In: Melby, E. C., Altmann, N. H. (ed.) Handbook of laboratory animal science, Vol. III. C.R.C. Press, Cleveland, Ohio, p. 343-356

Buchanan, R. E., Gibbons, N. E. (1974). Bergey's manual of determinative bacteriology. 8th edn. Witliams and Wilkins, Baltimore

Cooper, J. E., Jackson, O. (1981). Diseases of the Reptilia. Academic Press, London

Frye, F. L. (1973). Husbandry, medicine and surgery in captive reptiles. V. M. Publ. Inc., Bonner Springs

Glazebrook, J.S. (1981). Traumatic ulcerative dermatitis: a disease of captive sea turtles Chelonia mydas (L) in Northeast Australia. 4th. Int. Conf. Wildlife Dis. Sydney, Australia. Abstr p. 38

Hoff, G. L. (1984). Serratia. In: Hoff, G. L., Frye, F. L., Jacobson, E. R. (ed.) Diseases of amphibians and reptiles. Plenum Press, New York, p. 59-67

Hoff, G. L., Frye, F. L., Jacobson, E. R. (1984). Diseases of amphibians and reptiles. Plenum Press, New York, p. 25 51,94

Hoff, G. L., Hoff, D. M. (1984). Salmonella and Arizona. In: Hoff, G. L., Frye, F. L., Jacobson, E. R. (ed.) Diseases of amphibians and reptiles. Plenum Press, New York, p. 69-82

Humason, G. L. (1972). Animal tissue techniques. Freeman San Francisco

Jackson, C. G., Fulton, M. (1970). A turtle epizootic apparently of microbial origin. J. Wildlife Dis. 6: 466-468

Jackson, C. G., Fulton, M., Jackson, M. M. (1972). Cranial assymetry with massive infection in a box turtle. J. Wildlife Dis. 8: $275-277$

Jacobson, E. R. (1984). Pseudomonas. In: Holf, G. L., Frye F. L., Jacobson, E. R. (ed.) Diseases of amphibians and reptiles. Plenum Press, New York, p. 37-47

Kaplan, H. M. (1957). Septicemic, cutaneous ulcerative dis ease of turtles. Proc. Animal Care Panel 7: 273-277 
Marcus, L. C. (1980). Bacterial infections in reptiles. In: Murphy, J. B., Collins, J. T (ed.) Reproductive biology and diseases of captive reptiles, p. 211-221

Migaki, G., Jacobson, E. R., Casey, H. W (1984). Fungal diseases in reptiles. In: Hoff, G. L., Frye, F. L., Jacobson, E. R. (ed.) Diseases of amphibians and reptiles. Plenum Press, New York, p. 183-204

Rebell, G., Rywlin, A., Haines, H. (1975). A herpes-type agent associated with skin lesions of green sea turtles in aquaculture. Am. J. Vet. Res. 36: 1221-1224

Reichenbach-Klinke, H., Elkan, E. (1965). The principal diseases of lower vertebrates. Academic Press, New York
Shotts, E. B., Jr (1984). Aeromonas. In: Hoff, G. L., Frye, F. L., Jacobson, E. R. (ed.) Diseases of amphibians and reptiles Plenum Press, New York, p. 49-57

Wallach, J. D. (1976). The pathogenic etiology of ulcerative shell disease in turtles. J. Aquat. Mammals 4: 1-4

Wedemeyer, G., Wood, J. (1974). Stress as predisposing factor in fish diseases. U.S. Fish Wildlife Serv. Fish Dis. Leaflet No. $38: 1-8$

Witham, R. (1972). Focal necrosis of the skin in tank-reared sea turtles. J. Am. Vet. Med. Ass. 163: 656

Responsible Subject Editor: Professor P. Zwart; accepted for printing on September 4, 1987 